\title{
An Exploration of Learners' Attitudes towards Mobile Learning Technology-Based Instruction Module and its Use in Mathematics Education
}

\author{
Muthandwa Chinamhora Sincuba ${ }^{a}$, Merlin Johna
}

aWalter Sisulu University, SOUTH AFRICA

\begin{abstract}
The study explored learners' experiences with the mobile learning technology-based instruction module (MLTBIM) in learning Functions and related concepts. A sample of thirty-nine participants was purposefully drawn from the Grade 10 Mathematics classes in a selected historically disadvantaged rural senior secondary school. Adopting a case study research design, an attitude test was used in the collection of data. Microsoft Excel was used in presenting and analysing the data. The first finding of the study was that most respondents viewed the Mobile Learning Technology-Based application as very useful in the teaching and learning of Functions and related concepts. Secondly, most respondents upheld the view that Mobile Learning Technology-Based Instruction (MLTBI) was an effective method to learn Mathematics. Lastly, most of the respondents advocated that the application used in MLTBI enhanced their conceptual understanding of linear, quadratic and exponential functions. To conclude, the participants were convinced that cell phone devices and the Math4Mobile software were very useful and effective in the teaching and learning of Functions and related concepts regardless of the fact that there were some shortcomings involved.
\end{abstract}

KEYWORDS

attitudes, mathematics education, functions, Mobile Learning Technology-Based Instruction
ARTICLE HISTORY

Received 10 August 2017

Revised 28 September 2017

Accepted 15 November 2017

\section{Introduction}

"I believe that mathematics needs to be learned in creative ways, and not by memorization and repetition."(Prof Yerushalmy: University of Haifa, 2007).

\section{CORRESPONDENCE LD.A. Jazuli $₫$ salimpsa@gmail.com}

(c) 2017 M. John \& M. Sincuba.

Open Access terms of the Creative Commons Attribution 4.0 International License apply. The license permits unrestricted use, distribution, and reproduction in any medium, on the condition that users give exact credit to the original author(s) and the source, provide a link to the Creative Commons license, and indicate if they made any changes. (http://creativecommons.org/licenses/by/4.0/) 
Having achieved notable advances in education, South Africa needs to turn its attention to the quality of its mathematics education. Howie (2003) attests that South Africa spends proportionately more on education than many other countries, yet on international tests, South African learners' performance is of inferior quality compared to that of learners from other developing countries, including those in Africa. Bernstein (2011) confirms that South Africa is at or near the bottom in terms of learner performance in Mathematics and Science education. Furthermore, even though Mathematics, Science and Technology (MST) education has been a national priority in South Africa for several years, the number of learners who pass Grade 12 remains very low (Kriek \& Grayson, 2009). These statistics illustrate how learner achievement in mathematics education has become a serious concern. If South Africa is to participate effectively in the technologically advancing global village, it is imperative that research should inform policy and drive transformation in order to create a mathematically literate society.

For learners to be effective in their learning process, they need ability in reflective observation, concrete experience, abstract conceptualization and active experimentation (Kinsley, 2002); all these abilities subsequently affect their attitudes towards the learning of the subject. Howie (2001) and Khuzwayo (2005) attest that the acquisition of such skills depends on hard work and commitment as well as acquiring a positive attitude towards the study of Mathematics. When learners have a positive attitude towards the study of Mathematics, the majority perform better in the subject (Koller, Baumert \& Schnabel, 2001). Attitudes, as well as persistence, influence success in the study of Mathematics. Furthermore, Wilson (2008) attests that fostering positive attitudes in learners studying Mathematics will help them to engage in the subject productively instead of eliciting feelings of anxiety during Mathematics lessons. In concurrence, Sweeting (2011), asserts that exploring attitude formation provides valuable knowledge about the factors that contribute to the development of both positive and negative attitudes in learners of Mathematics.

Mji and Makgato (2006) reported on various factors that affect teaching and learning in general, and particularly those that impact on Mathematics and Science education. The factors which directly influence poor performance were found to be related to (a) teaching strategies; (b) content knowledge and understanding; (c) motivation and interest; (d) laboratory usage; and (e) syllabus non completion. Brodie (2004) and Maree (2007) concur with Mji and Makgato (2006) when they attest that achievement in Mathematics in secondary schools is influenced by such variables as learners' abilities, attitudes, family and socioeconomic status, parent and peer influences, school related variables such as a poor and non-stimulating learning environments, the learning culture, past racial discrimination and low expectations by principals and teachers. Brodie (2004) suggests that in traditionally disadvantaged schools, learning difficulties in Mathematics may originate from the learners' under-preparedness, teachers' presentation of the subject matter, lack of knowledge of the role of Mathematics in future career opportunities, or poor mathematical language background. Burstein (1992), in a comparative study of factors that influence Mathematics learning and achievement in Ontario, United States of America, found that, there was a direct link between learners' attitudes towards Mathematics and 
learners' outcomes. In a study conducted by Saha (2007) on gender, attitudes to Mathematics and achievement in Mathematics, it was found that all three variables contributed to a statistically-significant difference in achievement in Mathematics. Factors contributing to poor performance in Mathematics result in declining enrolments and poor performance of learners in the subject at all levels of the education system (Department of Basic Education (DoBE), 2012). Furthermore, due to these factors, small numbers of learners pass Mathematics at higher levels, especially at Grade 12 . The DoBE (2012) also attests that difficulty and the abstractness of Mathematics, inadequacy of many teachers' knowledge of and capacity to teach Mathematics, directly impact on learners' attitudes towards the subject. This inevitably leads to inadequacy of learner preparation at lower grades for higher grades and life beyond schooling.

In view of the factors alluded to above, the current teaching strategies have failed to enhance knowledge and conceptual understanding of Mathematics effectively among the learners and as a result, learners' performance in the subject is very dire. Moreover, these strategies have not succeeded much in developing a positive attitude among learners towards Mathematics. This might be one of the factors contributing to poor performance in the subject. To arouse positive attitudes among learners towards the subject, Mathematics educators and researchers have to consider exploring alternative teaching and learning strategies through which learners develop knowledge and conceptual understanding and positive attitudes towards Mathematics. In this context, technologically innovative approaches such as 'Mobile Learning Technologically' Based Instruction', are worthy of undertaking in South African schools.

Research findings reported that learners succeed academically in learning environments that match their learning strategies (Peker, 2005). It was found that learners' attitudes towards Mathematics are positively affected by welldesigned learning strategies. Some reform movements in Mathematics education encourage the use of technology in the classroom (Manoucherhri, 1999), particularly the use of computer- and cell phone-supported explorations as contexts for Mathematics instructions. Numerous academic studies showed the significant positive correlation between technology, student learning and Mathematics achievement (Kalloo \& Mohan, 2012). In support of this view, many researchers also reported on successful attempts at mobile learning in various disciplines. One of the pioneers in the field of mobile learning, Attewell (2005), reported that mobile learning assisted learners in building their selfesteem and self-confidence with technology. Moreover, Naismith and Corlett (2006) identified some positive outcomes of mobile learning projects such as motivation, engagement and collaboration. Stead (2005) confirmed that mobile learning is able to reach places that other methods of learning cannot; it is a bridge to Information Technology and it is suitable for collaboration and communication.

Lubega, McCrindle, Williams, Armitage and Clements (2004) conducted a survey among high school students in the United Kingdom regarding their attitudes towards mobile phones and learning. They established that most students felt positive about using the mobile phone for communication purposes (phone calls, SMS, MMS and emails), specifically group work, discussion, help 
offered to and from classmates, receipt of personalized information, communication with the teacher and issuing of spot quizzes. Another attitude survey conducted among elementary learners in Japan by Nagaki, Kobayashi and Nakagawa (2004) revealed that the learners tended to use the cell phones as tools for their learning, especially for communication purposes.

Faux, Mcfarlane, Roche and Facer (2006) reported on a study where primary school learners showed improvements in literacy after using Personal Digital Assistant (PDA). Furthermore, Cook, Bradley, Lance, Smith and Haynes (2007) reported on a mobile learning study where $73 \%$ of the learners thought it was convenient to learn anytime and anywhere. Attewell (2005) indicated that learners were excited to use the mobile devices; a large percentage of them showed improvement in reading and Mathematics skills and it helped build their self-esteem and confidence. Benta, Cremene and Padurean (2004) presented a multimedia mobile learning application that combined the advantages of text, images and audio. They stated that the mobile device captured the learners' attention very quickly and they found it useful.

Sharples (2003) described a system called HandLeR (Handheld Learning Resource) which attempted to put education at the fingertips of learners through their mobile device. He observed that the learners were excited about owning a piece of "cool" technology. The study indicated that the use of the mobile devices increases retention and motivation. In another study undertaken by Vahey and Crawford (2003), learners who used mobile devices for learning were reported to be more motivated than conventional learners. These researchers reported that the learners in their sample took more responsibility for their own learning and also took the initiative to discover new ways of using mobile hand-held devices in the learning situation.

The key findings of a number of studies in the m-learning project are summarised by Attewell (2005). According to this author, the use of mobile phones in teaching and learning tended to arouse enthusiasm among learners, improved the literacy and numeric skills of learners, encouraged independent and collaborative learning and, could be useful for identifying problem areas. Further, it could diminish the resistance that many people feel towards the use of mobile phone technology in education, help learners to learn to focus for longer periods and raise the self-esteem and confidence of individual learners. Hartnell-Young and Heym (2008) also conducted research to determine if there was a positive side to mobile phones in secondary schools; their findings revealed that learners enjoyed the mobile learning and were motivated. Kadirire (2007) used instant messaging for creating collaborative and interactive learning; the learners became engaged in course material outside the classroom which motivated them and improved their self-confidence. Moreover, most learners valued communication with peers and developed a sense of community.

Project K-Nect (2008) targeted learners "at-risk" in Grade 9, helping them to focus on increasing their Mathematics skills through mobile smartphones. There was a positive correlation between learners' participation in Project KNect and their proficiency levels in a standardized examination of the State of North Carolina. Furthermore, Kumar, Tewari, Shroff, Chittamuru, Kam and Canny (2010, p. 24) proposed that mobile devices like cell phones are a perfect vehicle for making educational opportunities accessible to rural children in 
places and times that are more convenient than formal schooling. They conducted a 26-week study to investigate the extent to which rural children voluntarily made use of mobile devices such as cell phones, to access educational content. Their results showed a reasonable level of academic learning and motivation.

The educational potential for mobile learning afforded by cell phone technology is diverse (Kolb, 2008; Prensky, 2005). Within South Africa a number of projects have already harnessed the ubiquity of cell phone technology to support the learning of Mathematics. A number of these projects are briefly outlined here in order to contextualise the growing potential for mobile learning through cell phone technology within the South African education landscape:

(i) ImfundoYami/ImfundoYethu is a mobile learning platform that delivers Mathematics education to Grade 10 learners through the instant messaging service MXit. Learners are able to access exercises and additional help. Mathematics teachers log into a web-based management system from which they can distribute exercises to the learners, provide personal support and monitor both results and learner activity (Vosloo, 2009).

(ii) The M4Girls project aims to improve the Mathematics performance of Grade 10 female learners in rural schools in South Africa. Learners are provided with cell phones containing a number of mini videos (2-3 minutes in length), mobile episode animations and games. All mathematical content is aligned with the South African Mathematics curriculum (Vosloo, 2008).

(iii) $M O B I^{T M}$ is a proprietary product that can be accessed through most Java-enabled cellphones. The product aims to provide mobile Mathematics education to Grade 10 to 12 learners and the content is specifically tailored for the South African Mathematics curriculum (Vosloo, 2007). MOBI ${ }^{\mathrm{TM}}$ maths provides the user with access to tutorials (in the form of streamed videos), past examination papers with solutions and an opportunity for learners to use closed chat rooms to form study or discussion groups (Botha, 2007).

(iv) Dr Math enables learners to access assistance with their homework assignments by interacting with tutors through MXit, a mobile instant messaging platform. In addition, Dr Math encourages drill and practice of basic skills through games and competitions via the MXit platform (Butgereit, 2009; Vosloo \& Botha, 2009).

Although the results showed improved achievements in the subject of Mathematics, the shortfalls of these projects were that they proved to be costly to most learners from historically-disadvantaged communities since they require data bundles or airtime to be accessed. Although there is reported research on the mobile learning technology instruction on teaching and learning of Mathematics, the researchers found none focusing on learners' attitudes towards mobile learning technology-based instruction during Mathematics classes throughout South Africa.

This gap prompted the researchers to consider the Mobile TechnologyBased Instruction strategy that integrates cell phone devices and Math4Mobile software. This medium makes educational opportunities as mobile as are 
learners. Moreover, cell phone devices facilitate the creation of a community of learners. The applications enable users to send graphs and formulas to one another via Blue-tooth and Share-it, allowing learners to work together in solving problems and to involve any number of people in the learning process. This novel learning environment supports the execution of mathematical tasks that are richer than traditional ones. Having the mathematical tool in hand at all times and in any place can support the mathematical modelling of real-world phenomena. It also provides learners and teachers with learning experiences that are relevant and meaningful for their everyday experiences. The minimum phone requirement is application (Java Enabled (J2ME) phone-profile/MIDP-2.0 Configuration/CLDC-1.1), which is compatible with most cell phones in use today. To implement this strategy, the researchers designed a Mobile Learning Technology-Based Instruction module on linear, quadratic and exponential functions based on Math4Mobile (a Mobile Learning Technology application) and assessed its effectiveness in promoting positive attitudes towards Mathematics. The following research question was posed:

What are the attitudes of the Grade 10 learners towards the mobile learning technology innovation and its use in Mathematics education?

\section{The Math 4 Mobile Application}

The researchers designed a teaching module on linear, quadratic and exponential functions based on a Mobile Learning Technology Application known as the Math4Mobile.The Math4Mobile platform was developed by Arik Weizman, Zohar Shavit and Michal Yerushalmy. The team was led by Michal Yerushalmy (Professor of Mathematics Education at the University of Haifa).The application was developed based on a successful technology-based curriculum for Geometry called VisualMath. This technologically innovative software aims to change the ways learners learn Geometry, function-based school Algebra and Calculus. Tools include a range of graphing calculators and dynamic Geometry tools, which encourage problem-solving through visualizing equations and the relationships between variables. The key features of Math4Mobile environment for this study are:

\section{Fit 2 Go 0.84}

This is a function graphing tool and curve fitter. Learners may view a phenomenon, identify variables, conduct experiments and take measurements in order to construct models of the phenomenon. It supports exploration and modelling activities and supports data collection by proposing a model that can appropriately describe the user's data. The tool highlights the numeric aspects of a phenomenon. It is suited for building a conceptual understanding of mathematical facts that are usually known only as the "rule of thumb". Fit2Go provides a wide repertoire of choices that fit given sets or subsets of data and elicits questions and conjectures that can lead to formal solutions and proofs.

Fit2Go 0.84 offers models by presenting graphs and expressions of functions that can fit the data. It also provides an easy visual way of entering the data by dynamically viewing the point and reading its values. Choosing the type of models is an important decision that should be made by the learner, rather than automatically interpreted by the tool. 


\section{Graph 2 Go 0.84}

Graph2Go is a special purpose graphing calculator that operates for given sets of function expressions. Graphing calculators are instrumental in the teaching and learning of Mathematics. It is an environment that supports conceptual understanding of functions in general, and school Algebra and analysis, in particular. It enhances connections between graphic and symbolic representations. A major objective of Algebra teaching is equipping learners with tools to mathematize their perceptions. A multi-representational approach has the potential to shift the focus of solving even traditional problems, from assigning and solving for an unknown, to analysing the various processes and relations among those processes.

The integration of multiple representation of function creates opportunities for developing a wider range of solution methods to traditional problems. Regarding the zooming in on the use of the graphing calculator, researchers point to the following patterns and modes of use:

- Computational tool;

- Visualizing tool; and

- Checking tool.

Dynamic control involves the direct manipulation of an object or a representation of a mathematical object. As the driving input is the lettersymbolic one, the transformations are carried out on the numbers involved in the function's expression. Thus, by parameterizing an example, we turn it into a family of functions. Research also suggests that the kinaesthetic relation between the user and the object on the screen can have an important role in developing a deeper understanding of the mathematical concept. Basic features of Graph2Go 0.84 are:

- Graphs of single variable function expression;

- Dynamic graphing of transformed expressions;

- Points of interest (maximum, minimum and inflection) are marked and their numerical values are presented;

- Graph and expression of the derivative function;

- Area expressed by the integral of a given function; and

- Zooming and rescaling options (University of Haifa, 2007).

The above features were useful in developing the teaching module. The main objective of designed module was to introduce participants to the mobile learning technology-based instruction in which they were to familiarise themselves with the various tools as well as navigations. The module also assisted participants to use the Cartesian plane on the cell phone interface, use the coordinate system to find co-ordinates, transform algebraic representations to graphical ones or vice versa. 


\section{Method}

\section{Sampling}

This study adopted a case study research design. The researchers used purposive sampling to select the sample from one intact class from a selected historically disadvantaged rural senior secondary school in the Dutywa district, Eastern Cape Province, South Africa. The sample for the study consisted of thirty-nine learners, drawn from one intact Grade 10 Mathematics class. The research sample consisted of the largest group of the targeted participants from the intact class at the research site. The research sampling technique was considered to be the most relevant since the researchers targeted the exploring attitudes of learners who had interacted with the MLTBI module and the cell phone devices during the teaching and learning of Functions and related concepts. Moreover, the researchers observed ethical considerations in conducting research at the selected research site by seeking written permission from the District Director; further all participants were assured of confidentiality by means of written notice.

\section{Data Collection Instrument}

The researchers developed a questionnaire which assessed the participants' attitudes towards the use of the Mobile Learning Technology-Based Instruction, particularly with the Math4Mobile software, on the teaching and learning of Functions and related concepts. The questionnaire consisted of 8 items and was rated on a five-point Likert scale. Johnson and Christensen (2012, p. 185), assert that the key advantage of multiple-item rating scales compared to the single-item scales is that multiple-item scales provide more reliable scores and they produce more variability, which helps the researchers make finer distinctions among the respondents. The Attitude Test (AT) in this study is aimed at evaluating the three dimensions which have relevance to teaching and learning of Functions and related concepts. The dimensions covered included:

a) Usage of Math4Mobile software in Functions and related concepts;

b) Interest in functions and graph functions with Math4Mobile; and

c) Self-Concept in functions and graph functions

The Attitude Test (AT) was validated by two experienced Mathematics teachers. They were informed of the purpose of the test and were requested to assess it. Generally, they were satisfied with the questions and also found it suitable for the learners. A pilot test was conducted in the neighbouring Senior Secondary School with a class of 30 Grade 10 Mathematics learners before the actual data collection. The pilot test was important to improve the language accuracy of the (AT) data collecting instrument. Comments and suggestions from the learners were taken down to assist in the actual data collection.

The data collected were analysed using Microsoft Excel. Participants' responses were calculated as percentages. These were then presented graphically before the data were analysed. 


\section{Results}

This section presents results of the first section of the attitude test instrument. The section assessed learners' attitudes towards the usefulness and effectiveness of the application in the teaching and learning of Mathematics (please see Table 1 and Chart 1).

From Chart 1, Items 1 to 5 show that $\pm 90 \%$ of the respondents are of the view that Mobile Learning Technology-Based Instruction is a useful method to learn Mathematics. In Item 1, $95 \%$ of the respondents suggest that the cell phone settings and the Math4Mobile software were easy to use during their Mathematics class. The second statement was aimed at finding out how the Mathematics learning activities on the phone helped participants to improve their mathematical skills when they used the software during the lessons. The analysis of the responses to this item shows that $92.31 \%$ of the participants responded that the software helped them to improve their mathematical skills, while $5.13 \%$ were not sure whether the cell phone activities helped them improve their mathematical skills. More than $90 \%$ of the respondents suggested that mobile learning is a flexible method of learning, can be done anytime and anywhere and improve communication between learner and educator (Items 3 and 4). These respondents also suggested that mobile learning can be a quicker method of getting feedback and support in learning. In Table 2 and Chart 2 , the participants' views on the shortcomings of mobile learning in education are reported:

In Item $6,90 \%$ of the respondents suggested that mobile learning may not be used for learning due to the unavailability of cell phone devices which are compatible with the software amongst a larger number of learners. In Item 7 , more than $80 \%$ of the respondents suggested that mobile learning may not be used for learning due to expenses involved. In Item 8, close to $50 \%$ learners disagreed with the statement that mobile learning may not be used for learning in rural areas due to poor networking.

\section{Discussion of the Findings}

This section discusses the major findings that emerged from the analyses of the responses from the attitude test which was administered to the participants only after the implementation of the mobile learning technologybased instruction module.

It was found that the respondents were of the view that mobile learning technology-based application was very useful in the teaching and learning of Functions and related concepts. It was also found that the feature of the software motivated the participants to want to learn more Mathematics. In conclusion, it was noted that the respondents felt that Math4Mobile application assisted them in improving their understanding of Functions and related concepts. This finding concurs with Kinsley (2002) who claimed that if learners are to be effective in their learning process, they need ability in reflective observation, concrete experience, abstract conceptualization and active experimentation, which subsequently affect their attitudes towards the learning of the subject. Furthermore, the findings concur with Koller, Baumert, and 
Schnabel (2001), who attest that when learners have a positive attitude towards the study of Mathematics, the majority performs better in the subject.

Based

Most respondents were of the view that Mobile Learning TechnologyThey Based Instruction in the teaching and learning of Functions and related concepts. These results once again confirmed the effectiveness of Mobile Learning Technology-Based Instruction in building a positive attitude among the participants as well as boosting their confidence, self-esteem and morale. Attitudes influence success as well as persistence in the study of Mathematics. In concurrence, Wilson (2008) attests that fostering positive attitudes in learners studying Mathematics will help them to engage in the subject productively instead of eliciting feelings of anxiety during Mathematics lessons.

The results of the study also revealed that most respondents gave the impression that Math4Mobile (the application used in Mobile Learning Technology-Based Instruction) enhanced their conceptual understanding of linear, quadratic and exponential functions. In a study conducted by Ornstein (1990, p. 35) it was concluded that the way an individual perceives the nature of the task at hand will influence attitudes, whether such influences seem to be internal or external. Naismith and Corlett (2006) also identified some positive outcomes of mobile learning projects such as motivation, engagement and collaboration. Moreover, in agreement with the findings of this study, Project KNect (2008) reported that there was a positive correlation between learners who actively participated in Project K-Nect and their final Algebra I proficiency level in a standardized examination.

Respondents preferred to use mobile-learning technology in other content areas of Mathematics. Most respondents were in favour of the cell phone devices and Math4Mobile application tools as motivation in teaching and learning of not only Functions and related concepts but other content areas of Mathematics. The findings are also consistent with Attewell (2005), who reported that the use of mobile phones in teaching and learning tended to arouse enthusiasm among learners, improved the literacy and numeric skills of learners, encouraged independent and collaborative learning, could be useful for identifying problem areas, and could diminish the resistance that many people feel towards the use of mobile phone technology in education. Further, it helped learners to focus for longer periods and raised the self-esteem and confidence of individual students. These findings concur with those by Hartnell-Young and Heym (2008), which revealed that learners enjoyed mobile learning and were motivated to continue to explore its use in the study of Mathematics.

\section{Conclusion and Recommendations}

The objective of this study was to explore learners' attitudes towards success in Mathematics through the Math4Mobile software in Mathematics classrooms and particularly in Functions and related concepts. The Math4Mobile application enabled the learners to examine the relation between the algebraic or symbolic, tabular and graphical representations of linear, quadratic and exponential functions by observing at least two representations on the same screen. Manipulating one of the variables and examining the changes on the other were also possible with the software. The study attempted to break 
the ground by piloting mobile teaching and learning as a mode of instruction to a group of Grade 10 Mathematics learners at a selected historically-disadvantaged rural Senior Secondary School. Furthermore, the study went against the grain by employing cell phone devices. These were very much enjoyed by learners. It tapped into the Math4Mobile application appreciated by the youth for the graphing of linear, quadratic and exponential functions.

It was found that most respondents agreed that the Mobile Learning Technology-Based application was very useful in the teaching and learning of Functions and related concepts. It was also found that most respondents were of the view that Mobile Learning Technology-Based Instruction was an effective method to learn Mathematics in general. The research objective was achieved in that participants were convinced that cell phone devices and the Math4Mobile software were very useful and effective in the teaching and learning of Functions and related concepts regardless of the fact that there were some shortcomings involved.

The recommendations from the study are that there might be a great need for schools to incorporate the MLTBI into the teaching and learning of Mathematics, which could help to improve the attitudes of learners towards the subject. Learners' cell phone devices could be useful if incorporated into learning activities to enhance teaching and learning. Well-planned and well-defined requirements for using cell phone devices for learning would need to be put in place. A practical investigation of MLTBI may be needed, and might have to be assessed for capturing the investigation results to evaluate the learners' performance while they are learning using mobile phone devices.

\section{Disclosure statement}

No potential conflict of interest was reported by the authors.

\section{Notes on contributors}

Muthandwa Chinamhora Sincuba - Walter Sisulu University, SOUTH AFRICA

Merlin John - Walter Sisulu University, SOUTH AFRICA

\section{References}

Archer, S. (2006). Ideas for teaching science. New York: Continuum International Publishing Group.

Attewell, J. (2005). Mobile technologies and learning: A technology update and m-learning project summary. Learning and Skills Development Agency: United Kingdom. http://www.mlearning.org/.

Babie, E.R. (2008). The Basics of Social Research. 4th ed. United States of America: Thomas Wadsworth publications.

Benta, K.I., Cremene, M. \& Padurean, R. (2004). Multimedia m-learning using mobile phones. In Proceedings of MLEARN 2004: Mobile Learning anytime everywhere, 5-6 July 2004, pp. 2728, Rome, Italy; London: Learning and Skills Development Agency.

Bernstein, A. (2011). Centre for Development and Enterprise Challenges the public education sector to form a social movement to improve education in South Africa. Mail \& Guardian, 21 September, 25p. 
Botha, A. (2007). Mobile education. Mail \& Guardian Online. Retrieved from http://www.mg.co.za/article/2007-08-01-mobile-education.

Broadbooks, W.J., Elmore, P.B., Pedersen, K. \& Bleyer, D.R. (1981). A Construct validation study of the Fennema- Sherman mathematics attitudes scale. Educational and Psychological Measurement, 41, 551-557.

Brodie K. (2004). Rethinking teachers' mathematical knowledge: A focus on thinking practice. Perspectives in Education, 22(1), 65-80.

Burstein, L. (1992). The analysis of multi-level data in educational research and evaluation. Review of Research in Education. 8, 158-223.

Butgereit, L. (2009). Using text adventure games to entice learners to practice arithmetic skills over Mxit. In J. H. Meyer \& A. Van Biljon (Eds.), Proceedings of the 15th Annual Congress of the Association of Mathematics Education of South Africa (Vol. 2, pp. 3-10). Bloemfontein: AMESA. Available at http://www.amesa.org.za/amesa2009/Proceedings.htm.

Chu, Y. \& Liu, T. (2007). Handheld computer supported context-aware learning with 2D barcodes. In Proceedings of the Seventh IEEE International Conference on Advanced Learning Technologies, (ICALT 2007), 18-20 July 2007, 485-486, Niigata, Japan.

Conway-Smith, E. (2010). Teaching with cell phones. GlobalPost.http://www.globalpost.com/dispatch/education/100720/south-africa-teaching-cellphones?

Cook, J., Bradley, C., Lance, J., Smith, C. \& Haynes, R. (2007). Generating learning contexts with mobile devices. Mobile learning: Towards a research agenda. WLE Centre Occasional Papers in Work-Based Learning, ed. Norbert Pachler, 55-74, London:WLE Centre. http://www.wlecentre.ac.uk/cms/files/occasionalpapers/mobilelearning_pachler2007.pdf

Department of Basic Education (2012). National Strategy for Mathematics, Science and Technology Education in General and Further Education and Training. Pretoria: Government Printers.

Department of Basic Education (2013). National Senior Certificate: Technical Report. Pretoria: Government Printers.

Eastern Cape Department of Basic Education (2014). National Senior Certificate: Technical Report. Pretoria: Government Printers. www.ecdoe.gov.za

Faux, F., Mcfarlane, A., Roche, N. \& Facer, K. (2006). Learning with handheld technologies: A handbook from Futurelab. Bristol, UK: Futurelab. http://www.futurelab.org.uk/research.

Federal Republic of Nigeria. (2004). National Policy on Education (Revised) NERC.

Glennie, J., Harley, K., Butcher, N. \& Van Wyk, T. ( 2012). Open Educational Resources and change in Higher Education: Reflections from practice. British Colombia: Vancouver.

Hartnell-Young, E. \& Heym, N. (2008). How mobile phones help learning in secondary schools? BECTA.http://research.becta.org.uk/index.php?catcode=_re_rp_02\&rid=15482\&section=rh, [17 November 2013].

Howie, S. J. (2003). Language and other background factors affecting secondary pupils' performance in Mathematics in South Africa. African Journal of research in Mathematics, Science and Technology Education, 7, 1-20.

http://www.scit.wlv.ac.uk/brendan/mLearn2008.pdf,[30 November 2013].

Johnson, B. \& Christensen, L. (2012). Educational Research. Quantitative, qualitative, and mixed approaches, 4th ed. Thousand Oaks, CA: Sage Publications.

Kadirire, J. (2007). Instant messaging for creating interactive and collaboration m-Learning environments. International Review of Research in Open and Distance Learning, 2(8),1-14.

Kahn, M. J. (1994). Science and Mathematics education in the formal system: Science and technology education and training for economic development. Johannesburg: Centre for Education Policy Development.

Kalloo, V. \& Mohan, P. (2012). MobileMath: an innovative solution to the problem of poor Mathematics performance in the Caribbean. Caribbean Teaching Scholar, 2(1), 5-18. 
Khuzwayo, B., (2005). A history of Mathematics education research in South Africa: The apartheid years. Researching Mathematics education in South Africa: Perspectives, practices and possibilities, $234,286 \mathrm{p}$.

Kinsley, J. (2002). A four stage model of mathematical learning. The Mathematics Educator Journal, $12(1), 11-16$.

Koller, O., Baumert, J. \& Schnabel, K. (2001). Does Interest Matter? The Relationship Between Academic Interest and Achievement in Mathematics. Journal for Research in Mathematics Education, 32 (5), 448-470.

Kriek, J. \& Grayson, D. (2009). A Holistic Professional Development model for South African Physical Science teachers. South African Journal of Education, 29, 185-203.

Kumar, A., Tewari, A., Shroff, G., Chittamuru, D., Kam, M. \& Canny, J. (2010). An Exploratory Study of Unsupervised Mobile Learning in Rural India. In CHI 2010, 10-15 April 2010, Atlanta, Georgia, USA.

Liebenberg, J. \& Conway-Smith. (2008). Mobile Mathematics-lessons learned. In Proceedings of the mLearn 2008 Conference, The Bridge From Text To Context, 7-10 October 2008, 346p.UK.Ironbridge Gorge: Shropshire.

Lubega, J., McCrindle, R., Williams, S., Armitage, U. \& Clements, I. (2004). Uses of mobile phones in higher education. In Cantoni and McLaughlin (eds) Proceedings of EDMEDIA 2004. Switzerland: Lugano.

Makgato M. \& Mji, A. (2006). Factors associated with high school learners' performance: A spotlight on mathematics and physical science. South African Journal of Education, 26(2), 253-266.

Manoucherhri, A. (1999). Computers and school mathematics reform: Implications for mathematics teacher education. Journal of Computers in Mathematics and Science Teaching, 18(1), 31-48.

Maree, K., (2007). First steps in Research. 1st ed. Pretoria: Van Schaik publishers.

McMillan, J.H. \& Schumacher, S. (2010). Research in education: Evidence-based inquiry. 7th ed. New York: Pearson.

MoMath, (2010). Mobile learning for Mathematics: Nokia project in South Africa Symbian tweet, http://www.symbiantweet.com/mobile-learning-for-Mathematics in South Africa, [20 February 2014]

Mulhern, F. \& Rae, G. (1998). Development of shortened form of the Fennema-Sherman mathematics attitude scales. Educational and Psychological Measurement, 41, 551-557.

Nagaki, T., Kobayashi, Y. \& Nakagawa, H. (2004). Attitude survey for pupils about using cellular phones in Classrooms. In Cantoni and McLaughlin (eds.) Proceedings of ED-MEDIA 2004, Switzerland: Lugano.

Naismith, L. \& Corlett, D. (2006). Reflections on success: A retrospective of the mLearn conference series 2002-2005. Paper presented at mLearn 2006 - Across generations and cultures. Canada. Banff. http://hal.archivesouvertes.fr/docs/00/19/73/66/PDF/Naismith-Corlett2006.pdf.

Ndafenongo, G. (2011). An investigation into how cell phones can be used in the teaching of Mathematics using Vitalmaths video clips: a case study of 2 schools in Grahamstown, South Africa. Thesis, Degree of Master of Education, Rhodes University (Faculty of Education), Grahamstown, South Africa.

Ornstein, A.C. (1990). Strategies for effective teaching. New York: McGraw-Hill Inc.

Peker, M. (2005).The relationship between learning styles and Mathematics achievement students' acquiring primary Mathematics teacher education. Eurasian Journal of Educational Research, 5 (21), 200-210.

Project K-Nect. (2008). http://www.projectknect.org/Project\%20K-Nect/Home.html http://www.cxc.org/examinations/exam-results-reports. [30 May 2014].

Retrieved from http://mlearningafrica.net/category/projects/ 
Saha, S. (2007). A study of Gender Attitude to Mathematics. Cognitive Style and Achievement in Mathematics. Experiments in Education 35(6).

Sharples, M. (2003). Disruptive devices: mobile technology for conversational learning. International Journal of Continuing Engineering Education and Lifelong Learning, 1(5\& 6), 504-520.

Stead, G. (2005). Moving mobile into the mainstream. In Proceedings of mLearn: Mobile technology: The future of learning in your hands, 25-28 October 2005, South Africa, Cape Town, London: WLE Centre.

Sweeting, K. (2011). Early Years Teachers' Attitudes in Mathematics. M.Ed Thesis. Queensland University of Technology. University of Haifa. http://construct.haifa.ac.il.

Vahey, P. \& Crawford, V. (2003). Learning with handhelds: Findings from classroom research. http://makingsens.stanford.edu/pubs/LearningFromHandhelds.pdf. [15 May 2014].

Vosloo, S. \& Botha, A. (2009). Mobile learning: South African examples. Paper presented at the Mobile Learning Institute Summit. Lusaka, Zambia. Retrieved from http://www.slideshare.net/stevevosloo/mobilelearning-south-african-examples.

Vosloo, S. (2007). MOBITM.

Vosloo, S. (2008). M4Girls. Retrieved from http://mlearningafrica.net/category/projects/

Vosloo, S. (2009). ImfundoYami/ImfundoYethu: Mobile learning for Mathematics. Retrieved from http://mlearningafrica.net/category/projects/

Wilson, P. (2008). Promoting positive attitudes. Retrieved November 10, 2015 from Electronic Resources Information Centre (ERIC) database (ERIC Document No EJ815090).

Xia, X., Lu, C. \& Wang, B. (2008). Research on Mathematics Instruction Experiment Based Problem Posing, Journal of Mathematics Education, 1(1),153-163.

Yerushalmy, M. \& Weizman, A. (2007). Math4Mobile mobile environments. The University of Haifa. http://www.math4mobile.com/[12 February 2014].

Yerushalmy, M. (2007). Math4Mobile mobile environments. The University of Haifa. http://www.math4mobile.com/ [12 February 2014] 